\title{
APLIKASI RHIZOBAKTERI PEMACU TUMBUH (RPT) DARI AKAR TITONIA (Tithonia diversifolia) TERHADAP PERTUMBUHAN STEK MELATI (Jasminum officinale) PADA ULTISOL
}

\author{
Agustian $^{1 *}$, Anisah Permata Sari ${ }^{1}$, dan Lusi Maira ${ }^{1}$ \\ ${ }^{1}$ Laboratorium Biologi Tanah Fakultas Pertanian Universitas Andalas \\ Kampus Limau Manis, Padang (25163) telp. 0751-72773, Fax. 0751-777061 \\ *Corresponding author, e-mail: agustian@faperta.unand.ac.id
}

\begin{abstract}
Jasmine plant is a horticultural crop that has promising prospect to be developed in trading. The development of jasmine cultivation is determined by the quality of seedling that can be produced rapidly for planting in the field. The purpose of this research is to study the effect of application of Plant growth-promoting rhizobacteria (PGPR) from titonia root (Tithonia diversifolia) in increasing the growth of jasmine cuttings (Jasminum officinale). This experiment used Completely Randomized Design (RAL) which consists of 7 treatments with 5 replications. The treatments were: A (control), B (Growtone), C (Growtone $+1 \mathrm{ml}$ PGPR), D (Growtone $+2 \mathrm{ml}$ PGPR), E (Growtone $+4 \mathrm{ml}$ PGPR), F (Growtone $+6 \mathrm{ml}$ PGPR) and $\mathrm{G}$ (Growtone $+8 \mathrm{ml}$ PGPR). Data obtained were analyzed statistically with $\mathrm{F}$ test at $5 \%$ level. The results showed that the application of PGPR can increase the growth of jasmine cuttings. However, the increase in PGPR dose did not have a significant effect on the increase of leaf number, branch number and height of jasmine cuttings. The highest number of leaves, branch and plant height at two months seedling age were found in treatment (C) $1 \mathrm{ml}$ PGPR with 48.60 leaves, 5.80 branch and $22.90 \mathrm{~cm}$ plant height that significantly different from other treatments,. Treatment (D) $2 \mathrm{ml}$ PGPR application increased the population of $\mathrm{P}$ solubilizing bacteria in rhizosphere from $2.59 \times 10^{4} \mathrm{cfu} / \mathrm{g}$ of soil at control to $5.05 \times 10^{5} \mathrm{cfu} / \mathrm{g}$ soil and fixing bacteria $\mathrm{N}$ (Azospirillium) $3 \times 10^{4} \mathrm{cfu} / \mathrm{g}$ soil to $1.41 \times 10^{5} \mathrm{cfu} / \mathrm{g}$ soil and Azotobacter to $1.2 \times 10^{3} \mathrm{cfu} / \mathrm{g}$ soil.
\end{abstract}

Key words : Jasmine, PGPR, cuttings, Ultisol

(C) 2018 Agustian Agustian, Anisah Permata Sari, Lusi Maira

\section{PENDAHULUAN}

Indonesia memiliki keragaman hortikultura yang berlimpah, dikarenakan keragaman sumberdaya lahan, iklim dan cuaca yang dimilikinya. Sumberdaya tersebut dapat dijadikan sumber kekuatan untuk menghadapi persaingan yang semakin ketat dalam agribisnis tanaman hortikultura dimasa depan. Menurut Wibowo (1999), tanaman hias dan hasilnya berupa bunga termasuk kelompok komoditas hortikultura yang mempunyai prospek cerah bila dikembangkan secara intensif dan komersil dan merupakan salah satu andalan Indonesia di pasar domestik, regional maupun international. Shukla (2013) menyebutkan kegunaan melati sangat beragam antara lain sebagai bahan rangkaian bunga, untuk tanaman hias, sebagai minyak atsiri yang digunakan dalam industri kosmetik, minuman, minyak wangi, minyak rambut dan sebagai obat. Data BPS (2016) menunjukkan bahwa Indonesia masih mengimpor minyak atsiri bunga dengan nilai US\$ 850.000. Sementara itu kebutuhan dunia akan minyak atsiri melati sekitar 4.000 ton per tahun. Sebagai gambaran minyak atsiri dari bunga melati di pasaran internasional adalah US \$ 527 per $500 \mathrm{~g}$ dan merupakan harga tertinggi kedua setelah bunga mawar.

Untuk mengembangkan perkebunan melati kebutuhan akan bibit melati yang banyak dan sehat sangatlah menentukan. Bibit yang unggul dan berkualitas baik akan lebih menjamin keberhasilan usaha yang dilakukan (Rukmana, 
1997). Tambahan lagi lahan-lahan yang potensial digunakan bagi pengembangan pertanian sebagian besar bereaksi masam seperti Ultisol. Disamping bereaksi masam Ultisol dikenal juga sebagai tanah yang miskin hara sehingga bibit melati yang berkualitas sangat diperlukan bagi keberhasilan tanaman melati di lapangan. Teknik perbanyakan vegetatif terutama dengan stek merupakan salah satu cara yang efisien dan efektif untuk memenuhi kebutuhan bibit melati dalam skala besar dalam waktu yang cepat. Menurut Hartman et al, (1996) penggunaan stek untuk perbanyakan bibit melati merupakan cara yang mudah dan umum digunakan dibanding kultur jaringan. Namun demikian menurut Heddy et al (1994) jenis dan ukuran stek yang digunakan sebagai bahan perbanyakan dari hasil penelitian menentukan keberhasilan perbanyakan tanaman. Penelitian Rein et al (1991) memperlihatkan bahwa tingkat kematangan bagian tanaman yang dijadikan bahan perbanyakan sangat perlu diperhatikan. Ditambahkan Blazich and Hinesley (1994), dan Struve (1981) bahwa keberhasilan tumbuh stek sangat ditentukan ratio karbohidrat/ nitrogen pada bahan stek.

Saat ini banyak dilakukan percepatan pertumbuhan dengan cara memberi zat pengatur tumbuh dengan kadar tertentu untuk mempercepat produksi. Salah satu zat pengatur tumbuh yang paling umum digunakan adalah rootone-F yang termasuk dalam kelompok auksin dan berguna untuk mempercepat serta memperbanyak keluarnya akar-akar baru karena mengandung bahan aktif dari hasil formulasi beberapa hormon tumbuh akar yaitu IBA, IAA, dan NAA (Sarwar et al, 1992). Cara alternatif yang bisa digunakan bagi percepatan pertumbuhan adalah dengan menginokulasi bibit melati dengan rhizobakteri pemacu tumbuh. Pengaruh mikrobia tanah menurut Kloepper et al (2004) dan Glick (1995) terhadap pertumbuhan tanaman sangat penting karena dapat meningkatkan poduktivitas tanaman dan mempertahankan kesuburan tanah. Jazad renik tanah dapat membawa perubahan pada pertumbuhan tanaman, terutama yang bersifat mendorong pertumbuhan tanaman. Penelitian yang dilakukan oleh Agustian (2008 dan 2009), dengan mereinokulasikan rhizobakteria dari titonia pada tanaman jagung dan kedelai, Hakim et al (2014) pada bibit titonia membuktikan bahwa rhizobakteria asal titonia dapat dimanfaatkan tidak hanya membantu pertumbuhan titonia tetapi juga untuk tanaman lainnya. Berdasarkan hasil penelitian itulah rangkaian penelitian ini dilakukan dengan tujuan mempelajari pengaruh aplikasi rhizobakteri pemacu tumbuh asal titonia terhadap pertumbuhan bibit tanaman melati yang ditumbuhkan pada media tanah berjenis Ultisol.

\section{BAHAN DAN METODA}

Perbanyakan isolat dilakukan di Laboratorium Biologi Tanah, sedangkan analisis kinia tanah dilakukan pada laboratorium Kimia Tanah. Percobaan pot dilakukan di rumah setengah bayangan pada kebun percobaan Fakultas Pertanian Universitas Andalas di Limau Manis Padang. Untuk percobaan pot jumlah tanah yang digunakan adalah $3 \mathrm{~kg}$ setara kering mutlak. Stek melati (Jasminum officinale) yang digunakan adalah stek batang yang mempunyai 4 mata tunas. Bahan stek ini dihasilkan dari tanaman induk yang telah besar dan memiliki cabang dan telah berkayu. Ukuran panjang stek yang digunakan $10-15 \mathrm{~cm}$ yang diambil dari cabang dengan diameter batang sekitar $0,5 \mathrm{~cm}$. Rancangan percobaan yang digunakan adalah RAL dengan 7 perlakuan dan ulangan 5 kali: A (kontrol); B (GrowTone); C (GrowTone + $1 \mathrm{ml}$ BPF, BPFH, BPN); D (GrowTone $+2 \mathrm{ml}$ $\mathrm{BPF}, \mathrm{BPFH}, \mathrm{BPN}$ ); E (GrowTone $+4 \mathrm{ml}$ $\mathrm{BPF}, \mathrm{BPFH}, \mathrm{BPN}$ ); $\mathrm{F}$ (GrowTone $+6 \mathrm{ml}$ $\mathrm{BPF}, \mathrm{BPFH}, \mathrm{BPN}$ ); G (GrowTone $+8 \mathrm{ml}$ BPF, BPFH, BPN). Rhizobakteri yang dicobakan adalah BPF (Bakteri Pelarut Fosfat) , BPFH (Bakteri Penghasil Fitohormon), dan BPFN (Bakteri Pemfiksasi $\mathrm{N})$ dengan kerapatan populasi $10^{8} \mathrm{cfu}$ per $\mathrm{ml}$.

Media yang digunakan sebagai media pembibitan merupakan tanah Ultisol yang sebelum digunakan dianalisis sifat dan ciri tanahnya meliputi analisis $\mathrm{pH} \mathrm{H}_{2} \mathrm{O}$ dan $\mathrm{KCl}$, C-org, N-total, KTK, Ca-dd, Mg-dd, K-dd dan Na-dd, Al-dd dan P-tersedia. Kandungan Al-dd 
tanah dijadikan patokan dalam menentukan jumlah kapur yang diberikan. Pengapuran tanah menggunakan kapur dolomit dengan takaran 1,5xAl-dd, setelah dikapur diberi pupuk kandang sebanyak $10 \%$ dari berat tanah, kemudian disiram sampai kapasitas lapang dan diinkubasi selama 3 minggu. Pengamatan sifat kimia tanah setelah inkubasi kapur meliputi $\mathrm{pH}$ dan kandungan Al-dd. Pengamatan terhadap bibit dilakukan meliputi waktu muncul tunas, jumlah tunas, dan jumlah daun. Inokulan rhizobakteri diberikan sebanyak 4 kali selang waktu 2 minggu dengan dosis sesuai dengan perlakuan bertujuan untuk meminimalisir penurunan populasi rhizobakteri selama percobaan. Perhitungan total populasi dilakukan dengan metode pengenceran. Pengenceran yang dilakukan sampai $10^{-6}$. Jumlah populasi bakteri pemfiksasi $\mathrm{N}$ dan pelarut $\mathrm{P}$ dihitung dengan menggunakan metode cawan tuang. Data hasil pengamatan di uji $\mathrm{F}$ menggunakan analisis ragam dan jika hasil pengujian berbeda nyata maka dilanjutkan dengan uji lanjut wilayah berganda Duncan (DNMRT) pada taraf 5\%.

\section{HASIL DAN PEMBAHASAN}

\section{Sifat kimia tanah awal dan setelah inkubasi kapur}

Hasil analisis awal sifat kimia tanah masam yang diambil dari kebun percobaan Fakultas Pertanian Universitas Andalas mempunyai tingkat kesuburan tanah yang rendah. Hal ini dapat dilihat pada Tabel 1 yang menunjukkan kondisi kimia tanah yang kurang baik seperti $\mathrm{pH}$ tanah yang masam, kandungan C-Organik yang sangat rendah, KTK rendah, Al-dd sedang, $\mathrm{P}$ tersedia yang rendah, K-dd rendah, Ca-dd sangat rendah, Mg-dd rendah, dengan kejenuhan basa sedang dan kejenuhan Al juga sedang.

Tabel 1. Hasil analisis sifat dan ciri kimia contoh tanah awal yang digunakan untuk percobaan pot

\begin{tabular}{|c|c|c|c|}
\hline \multirow[t]{2}{*}{ No } & \multirow[t]{2}{*}{ Ciri kimia tanah } & \multicolumn{2}{|c|}{ Nilai* } \\
\hline & & Awal & Setelah inkubasi kapur \\
\hline 1 & $\mathrm{pH} \mathrm{H} \mathrm{H}_{2} \mathrm{O}(1: 2)$ & $5,59^{\mathrm{m}}$ & $5,96^{\mathrm{am}}$ \\
\hline 2 & $\mathrm{pH} \mathrm{KCl} \quad(1: 2)$ & 4,81 & 5,39 \\
\hline 3 & C-organik (\%) & $1,7^{\mathrm{r}}$ & - \\
\hline 4 & N-total (\%) & $0,23^{\mathrm{s}}$ & - \\
\hline 5 & P-tersedia (ppm) & $16,76^{\mathrm{s}}$ & - \\
\hline 6 & KTK (me/100g) & $9,84^{\mathrm{r}}$ & - \\
\hline 7 & $\mathrm{~K}(\mathrm{me} / 100 \mathrm{~g})$ & $0,49^{\mathrm{s}}$ & - \\
\hline 8 & $\mathrm{Na}(\mathrm{me} / 100 \mathrm{~g})$ & $0,34^{\mathrm{t}}$ & - \\
\hline 9 & $\mathrm{Ca}(\mathrm{me} / 100 \mathrm{~g})$ & $0,76^{\text {sr }}$ & - \\
\hline 10 & $\operatorname{Mg}(\mathrm{me} / 100 \mathrm{~g})$ & $0,59^{r}$ & - \\
\hline 11 & Al-dd (me/100g) & 1,46 & tu \\
\hline 14 & $\mathrm{H}-\mathrm{dd}(\mathrm{me} / 100 \mathrm{~g})$ & 0,2 & - \\
\hline 15 & $\mathrm{C} / \mathrm{N}$ & $7,4^{\mathrm{r}}$ & - \\
\hline
\end{tabular}

Keterangan : am: agak masam, sr:sangat rendah, r:rendah, st:sangat tinggi, t:tinggi; s:sedang; tu= tidak terukur

Sumber* : Staf pusat penelitian tanah (1983) cit Hardjowigeno, (2010)

Setelah inkubasi kapurdapat nilai $\mathrm{pH}$ $\mathrm{H}_{2} \mathrm{O}$ meningkat dari 5,59 menjadi 5,96 dan $\mathrm{pH}$ $\mathrm{KCl}$ dari 4,81 menjadi 5,42 dan kandungan Aldd turun menjadi tidak terukur. Pemberian dengan kapur dapat menetralisir Al melalui ion
$\mathrm{OH}^{-}$yang dihasilkannya dari pelepasan ion $\mathrm{CO}_{3}{ }^{2-}$, di samping itu gugus fungsional yang dihasilkan pupuk kandang selama inkubasi akan mengikat Al sehingga $\mathrm{Al}$ menjadi tidak larut yang selanjutnya Al-dd tanah menjadi 
berkurang. Sanchez (1992) menyatakan bahwa ion $\mathrm{CO}_{3}^{2-}$ dari kapur dibutuhkan untuk menghasilkan ion $\mathrm{OH}^{-}$yang dapat menarik $\mathrm{Al}$ sehingga terbentuk $\mathrm{Al}(\mathrm{OH})^{3}$ yang tidak aktif. Menurut (Hakim, 1983), pengapuran berguna untuk mengurangi kemasaman tanah atau menaikkan $\mathrm{pH}$ tanah, dengan jalan menambah jumlah kation-kation terhadap sifat kimia tanah dengan pengapuran dapat menurunkan kelarutan Al, Mn dan, Fe.

\section{Pengaruh dosis RPT terhadap pertumbuhan stek melati}

Pada Tabel 2 dapat dilihat bahwa peningkatan volume $(\mathrm{ml})$ inokulan RPT yang digunakan tidak berpengaruh nyata terhadap tinggi tanaman melati. Peningkatan inokulan RPT sampai $8 \mathrm{ml}$ sebaliknya menekan pertumbuhan stek tanaman melati yaitu hanya mencapai 13,40 cm. Hal yang sama juga ditemukan pada jumlah daun dimana pada perlakuan $8 \mathrm{ml}$ didapatkan hanya 31,2 helai daun saja. Peningkatan dosis RPT terlihat tidak mempengaruhi jumlah cabang stek. Tinggi tanaman serta jumlah daun terbanyak justeru didapatkan pada perlakuan dengan $1 \mathrm{ml}$ RPT Ini menandakan bahwa pemberian inokulasi dengan dosis yang lebih tinggi menyebabkan penghambatan pertumbuhan tanaman. Selain inokulasi pemberian zat pengatur tumbuh juga berdampak bagi tanaman. Menurut Husen dan Saraswati (2003) bahwa rhizobakteri penghasil hormon IAA (Asam Indol Asetat) dapat memberikan dampak negatif bagi tanaman. Penelitiannya pada tanaman cabai (Capsicum annuum L.) yang diinokulasi dengan berbagai isolat rhizobakteri penghasil IAA menunjukkan respon negatif tanaman. Kedua kondisi yang berbeda ini juga mengindikasikan bahwa ada mekanisme lain yang menghambat pertumbuhan tanaman terkait dengan peningkatan konsentrasi IAA.

Tabel 2. Pengaruh aplikasi RPT terhadap tinggi tanaman, jumlah daun dan cabang melati umur 9 minggu

\begin{tabular}{|c|c|c|c|}
\hline Perlakuan & Tinggi tanaman $(\mathrm{cm})$ & $\begin{array}{l}\text { Jumlah daun } \\
\text { (helai) }\end{array}$ & Jumlah cabang (buah) \\
\hline A Kontrol & $17,80 \mathrm{a}$ & $34,00 \mathrm{~b}$ & $4,80 \mathrm{a}$ \\
\hline Growtone & $17,90 \mathrm{a}$ & $29,20 \mathrm{~b}$ & $4,00 \mathrm{a}$ \\
\hline Growtone $+1 \mathrm{ml} \mathrm{RPT}$ & $22,90 \mathrm{a}$ & $48,60 \mathrm{a}$ & $5,80 \mathrm{a}$ \\
\hline D Growtone $+2 \mathrm{ml} \mathrm{RPT}$ & $18,20 \mathrm{a}$ & $37,80 \mathrm{ab}$ & $4,80 \mathrm{a}$ \\
\hline Growtone $+4 \mathrm{ml} \mathrm{RPT}$ & $22,40 \mathrm{a}$ & $42,80 \mathrm{ab}$ & $5,40 \mathrm{a}$ \\
\hline $\mathrm{F} \quad$ Growtone $+6 \mathrm{ml} \mathrm{RPT}$ & $20,90 \mathrm{a}$ & $40,80 \mathrm{ab}$ & $5,00 \mathrm{a}$ \\
\hline $\mathrm{G}$ Growtone $+8 \mathrm{ml}$ RPT & $13,50 \mathrm{~b}$ & $31,20 \mathrm{~b}$ & $4,20 \mathrm{a}$ \\
\hline
\end{tabular}

Keterangan: Angka-angka pada kolom yang sama berbeda tidak nyata menurut uji DNMRT pada taraf $5 \%$.

Glick (1995) dan Mayak et al. (1997) menyatakan bahwa produksi IAA yang berlebihan akan memacu pembentukan hormon etilen yang dalam konsentrasi tinggi justru menghambat perkembangan/pemanjangan akar. Enzim aminocyclopropane carboxylic acid (ACC) deaminase berperan mengurangi pembentukan ACC yang merupakan bahan dasar pembentukan hormon etilen. Imaseki (1986) menyatakan hormon etilen selain berfungsi sebagai pemacu tumbuh (mempercepat perkecambahan, perkembangan akar, pembungaan, pematangan buah) juga berperan sebagai antagonis atau modulator bagi berbagai fitohormon untuk mencegah pertumbuhan tanaman yang berlebihan (gigantisme). Menurut Mullins (1972) pembentukan (sintesis) ACC dipacu oleh hormon IAA, dan ACC yang terbentuk akan diubah menjadi hormon etilen yang dalam jumlah besar menghambat pemanjangan (perkembangan) akar baru. Pada perlakuan dengan $1 \mathrm{ml}$ inokulan RPT menunjukkan jumlah daun yang paling banyak dan ini menandakan pemberian inokulan RPT dengan dosis yang sedikit dibutuhkan untuk 
meningkatkan produktivitas tanaman. Penelitian Tien et al. (1979) menggunakan Azospirillum brasilliense pada tanaman pearl millet (Pennisetum americanum L.) memperlihatkan hasil yang sama, pada konsentrasi lebih tinggi cenderung menurunkan pertumbuhan.

\section{Pengaruh aplikasi RPT terhadap total populasi bakteri, BPF dan BPFN pada rhizosfir stek melati}

Pada Tabel 3 dapat dilihat bahwa aplikasi RPT menunjukkan pengaruh yang berbeda nyata walaupun RPT yang digunakan tidak secara linier meningkatkan total populasi bakteri. Total populasi tertinggi ditemukan pada perlakuan $\mathrm{F}$ dengan 6 $\mathrm{ml}$ RPT yaitu sebesar 7,5780 cfu/tanah diikuti dengan perlakuan $\mathrm{C}(1 \mathrm{ml} \mathrm{RPT})$ dan $\mathrm{D}(2 \mathrm{ml}$
RPT) yang berbeda nyata dengan perlakuan $\mathrm{F}$ tetapi tidak berbeda nyata antar keduanya. Peningkatan volume RPTmenjadi $8 \mathrm{ml}$ pada perlakuan $\mathrm{G}$ sebaliknya menurunkan total populasi. Hasil pengamatan ini menunjukkan peningkatan pemberian RPT tidak merubah jumlah total populasi di rhizosfir tanaman melati malah sebaliknya menurunkan total populasi bakteri. Hasil penelitian Agustian et al (2010) menunjukkan bahwa perbedaan total populasi sangat dipengaruhi oleh reaksi tanah dan pada umumnya bakteri lebih dominan pada tanah- tanah yang ber $\mathrm{pH}$ netral. Hasil ini diperkuat oleh penelitian Kokalis-Burelle et al (2006) yang mengemukan bahwa $\mathrm{pH}$ tanah sangat mempengaruhi pertumbuhan dan aktivitas dari bakteri di dalam tanah. Kebanyakan bakteri hidup paling baik dan aktivitasnya lebih tinggi pada $\mathrm{pH} 7,0$.

Tabel 3. Pengaruh inokulasi rhizobakteri terhadap total populasi rhizobakteri, BPF dan BPFN umur melati 9 minggu (data ditransformasi Log jumlah populasi)

\begin{tabular}{|c|c|c|c|c|c|}
\hline \multirow{2}{*}{\multicolumn{2}{|c|}{ Perlakuan }} & \multirow{2}{*}{ Total populasi } & \multirow{2}{*}{$\mathrm{BPF}$} & \multicolumn{2}{|c|}{ BPFN } \\
\hline & & & & Azotobacter & Azospirillum \\
\hline A & Kontrol & $7,3380 \mathrm{bc}$ & $4,41 \mathrm{c}$ & $2,56 \mathrm{a}$ & $4,47 \mathrm{bc}$ \\
\hline B & Growtone & $7,4320 \mathrm{~b}$ & $4,46 \mathrm{c}$ & $2,00 \mathrm{a}$ & $4,29 \mathrm{~d}$ \\
\hline $\mathrm{C}$ & Growtone $+1 \mathrm{ml} \mathrm{RPT}$ & $7,1960 \mathrm{c}$ & $4,71 \mathrm{~b}$ & $3,46 \mathrm{a}$ & $4,54 \mathrm{~b}$ \\
\hline $\mathrm{D}$ & Growtone $+2 \mathrm{ml} \mathrm{RPT}$ & $7,2680 \mathrm{c}$ & $5,71 \mathrm{a}$ & $3,48 \mathrm{a}$ & $5,15 \mathrm{a}$ \\
\hline $\mathrm{E}$ & Growtone $+4 \mathrm{ml} \mathrm{RPT}$ & $7,4720 \mathrm{ab}$ & $4,77 \mathrm{~b}$ & $2,57 \mathrm{a}$ & $4,87 \mathrm{ab}$ \\
\hline $\mathrm{F}$ & Growtone $+6 \mathrm{ml} \mathrm{RPT}$ & $7,5780 \mathrm{a}$ & $4,75 \mathrm{~b}$ & $3,70 \mathrm{a}$ & $4,40 \mathrm{c}$ \\
\hline G & Growtone $+8 \mathrm{ml} \mathrm{RPT}$ & $7,3880 \mathrm{bc}$ & $4,76 \mathrm{~b}$ & $3,70 \mathrm{a}$ & $4,50 \mathrm{~b}$ \\
\hline
\end{tabular}

Keterangan: Angka-angka pada kolom yang sama berbeda tidak nyata menurut uji DNMRT pada taraf $5 \%$.

Peningkatan volume RPT meningkatkan populasi bakteri pelarut $\mathrm{P}(\mathrm{BPF})$ walaupun peningkatan volume aplikasi tidak konsisten terhadap peningkatan populasi. Populasi BPF tertinggi ditemukan pada perlakuan D (2 ml). Peningkatan volume lebih tinggi justru menurunkan populasi BPF. Mikroba disekitar tanaman jumlah populasinya tergantung kepada kepekaan mikroba itu sendiri, kesuburan tanah, kelembaban, dan intensitas cahaya, serta temperatur tanah. Menurut Kucey (1983) umumnya 
mikroorganisme pelarut fosfat secara alami berada di tanah populasinya berkisar $0,1-0,5 \%$ dari total populasi mikroorganisme. Populasi mikroorganisme pelarut fosfat dari kelompok bakteri jauh lebih banyak dibandingkan dengan kelompok fungi. Pertumbuhan mikroorganisme pelarut fosfat sangat dipengaruhi oleh kemasaman tanah. Pada tanah masam, aktivitas mikroorganisme didominasi oleh kelompok fungi sebab pertumbuhan fungi optimum pada $\mathrm{pH}$ 5-5,5. Menurut Barea et al (1976) aktivitas mikroorganisme pelarut fosfat sangat tergantung pada $\mathrm{pH}$ tanah. Kecepatan mineralisasi juga meningkat dengan nilai $\mathrm{pH}$ yang sesuai bagi metabolisme mikroorganisme dan pelepasan fosfat akan meningkat dengan meningkatnya nilai $\mathrm{pH}$ dari asam ke netral.

Dari tabel 3 dapat dilihat bahwa populasi bakteri penambat $\mathrm{N}$ yang tumbuh dalam media DL Malic acid menunjukkan hasil berbeda nyata. Perlakuan D dengan populasi tertinggi yaitu 5,15 berbeda sangat nyata dengan perlakuan $\mathrm{B}$ dengan populasi sebesar terendah yaitu 4,29 dan. Pada perlakuan A (kontrol) memiliki nilai populasi 4,47 lebih tinggi dibandingkan dengan perlakuan $F$ dengan populasi 4,40. Berbeda dengan perlakuan $\mathrm{G}$ dengan inokulasi $8 \mathrm{ml}$ dengan populasi sebesar 4,50 cendrung lebih tinggi dari pada perlakuan F. Ini diduga karena saat rhizobakteri diinokulasi ke tanah biasanya bakteri akan beradaptasi dengan lingkungan baru, kemudian bakteri akan mulai melakukan aktivitas dengan merombak bahan organik tanah sehingga bakteri Azospirillium dapat melakukan aktivitas untuk berkembang dan membantu pertumbuhan tanaman.

Salah satu faktor yang terpenting dalam aktivitas bakteri ini yaitu keberadaan bahan organik sebagai sumber nutrisi bagi bakteri. Faktor lain ialah untuk menunjang aktivitas bakteri Azospirillum ialah $\mathrm{pH}$ tanah, karena bakteri Azospirillum dapat tumbuh dan aktif beraktivitas dengan pada kondisi $\mathrm{pH}>6$ dan lebih baik pada $\mathrm{pH}$ netral. Azospirillum merupakan bakteri yang bersifat simbiosis asosiatif untuk menyebutkan adanya pemfiksasi nitrogen dalam tanaman. Bakteri Azospirillum membutuhkan kondisi oksigen rendah, dan dapat tumbuh cepat pada lingkungan yang mengandung amonium tanpa memfiksasi nitrogen. Azospirillum merupakan bakteri yang dapat mendorong pertumbuhan berbagai jenis tanaman, dimana kemampuan yang menguntungkan ini karena kemampuannya menghasilkan fitohormon, termasuk giberelin (Okon dan Labandera González,1994).

Populasi dari bakteri penambat $\mathrm{N}$ Azotobacter tidak memperlihatkan pengaruh yang berbeda nyata terhadap populasi bakteri penambat $\mathrm{N}$ genus Azotobacter. Pada perlakuan $\mathrm{F}$ dan $\mathrm{G}$ populasi bakteri yang ditumbuhkan pada media agar sukrosa garam mineral memiliki jumlah populasi yang sama yaitu 3,70. Untuk perlakuan $C$ dan $D$ memiliki nilai populasi yang hampir sama yaitu 3,46 dan 3,48. Aktivitas bakteri Azotobacter tidak menunjukkan aktivitasnya yang aktif. Populasi bakteri Azotobacter sangat dipengaruhi oleh ketersediaan nutrisi yang mendukung pertumbuhannya. Faktor utama yang harus diperhatikan dalam aplikasi Azotobacter adalah kandungan bahan organik dalam tanah yang merupakan sumber nutrisi bagi bakteri. Selain eksudat akar tanaman yang banyak mengandung asam amino, karbohidrat dan senyawa lainnya sebagai sumber energi dan nutrisi bagi pertumbuhan mikroba, aktivitas dan populasi mikroba didaerah perakaran tanaman juga dipengaruhi oleh kandungan bahan organik tanah. Selain bahan organik, $\mathrm{pH}$ tanah juga mempengaruhi populasi dari bakteri Azotobacter. Kloepper et al (2004), menemukan kolerasi antara $\mathrm{pH}$ tanah dan populasi Azotobacter sp, salah satu bakteri penambat $\mathrm{N}$ non simbiotik, yang mana kemasaman tanah $(\mathrm{pH}<7,0)$ diikuti oleh penurunan populasi Azotobacter sp.

Azotobacter tersebar luas dalam tanah, walaupun demikian hanya jumlah-jumlah yang relatif terbatas dari sel-sel yang ditemukan dalam tiap tanah tertentu. Faktor-faktor yang dibutuhkan untuk populasi Azotobacter yaitu reaksi pada tanah, melimpahnya bahan organik, konsentrasi elemen mineral tertentu terutama fosfat serta mikrorganisme antagonis (Kokalis-Burelle, 2004). 


\section{KESIMPULAN}

Dari penelitian ini dapat disimpulkan bahwa aplikasi rhizobakteri pemacu tumbuh (RPT) dari akar titonia dapat meningkatkan pertumbuhan stek melati walaupun tidak secara nyata pada tinggi dan jumlah cabang tetapi secara nyata berpengaruh pada jumlah daun. Volume RPT $(2 \mathrm{ml})$ dengan populasi $10^{8} \mathrm{cfu}$ per $\mathrm{ml}$ memperlihatkan pertumbuhan stek melati yang terbaik, peningkatan volume RPT lebih tinggi tidak lagi memberi pengaruh yang nyata bagi stek melati. Volume RPT $(2 \mathrm{ml})$ dengan populasi $10^{8} \mathrm{cfu}$ per $\mathrm{ml}$ yang diberikan di daerah perakaran stek melati memiliki tingkat populasi rhizobakteri yang bervariasi tetapi total populasi rhizobakteri tidak dipengaruhi oleh peningkatan volume inokulan. Penggunaan volume $2 \mathrm{ml}$ RPT mampu meningkatkan pertumbuhan bakteri pelarut $\mathrm{P}$ (BPF) dan Pemfiksasi N (BPFN) walaupun belum mampu meningkatkan pertumbuhan tanaman.

\section{UCAPAN TERIMAKASIH}

Penelitian ini merupakan bahagian dari skim penelitian hortikultura yang dibiayai dari dana BOPTN Universitas Andalas.

\section{DAFTAR PUSTAKA}

Agustian. 2008. Interaksi Mikrobia Pemacu Tumbuh pada Rhizosfir Tithonia dengan Tanaman Pangan dalam Sistem Penanaman Pagar Lorong. Laporan Penelitian Fundamental Tahun I. Proyek Peningkatan Penelitian Perguruan Tinggi DP2M Ditjen Dikti. Lembaga Penelitian Unand. Padang

Agustian. 2009. Interaksi Mikrobia Pemacu Tumbuh pada Rhizosfir Tithonia dengan Tanaman Pangan dalam Sistem Penanaman Pagar Lorong. Laporan Penelitian Fundamental Tahun II. Proyek Peningkatan Penelitian Perguruan Tinggi DP2M Ditjen Dikti. Lembaga Penelitian Unand. Padang
Agustian, Nuriyani, Lusi Maira dan Oktanis Emalinda. 2010. Rhizobakteria penghasil Fitohormon IAA pada rhizosfir tumbuhan semak karamunting, titonia dan tanaman pangan. J.Solum. Vol VII No. $1: 49-60$

Barea, J. M., E. Navarro, and E. Montoya. 1976. Production of plant growth regulators by rhizosphere phosphatesolubilizing bacteria. J. Appl. Bacteriol. 40: $129-134$

Blazich, F.A. and L.E. Hinesely. 1994. Propagation of fraser fir. J. Environ. Hort. 12:112-117

BPS. 2016. Statistik tanaman hias Indonesia. 91 hal. https://www.bps.go.id/website/pdf_publik asi/Statistik-Tanaman-Hias-Indonesia2016.pdf

Glick, B.R. 1995. The enhancement of plant growth by free-living bacteria. Can J. Microbiol. 41: 109-117

Hakim, N., R. Alfina, Agustian, Hermansah and Yulnafatmawita. 2014. Bacterial Inoculants to Increase the Biomass and Nutrient Uptake of Tithonia Cultivated as Hedgerow Plants in Ultisols. Malaysian Journal of Soil Science (18) p. 115-123

Hardjowigeno, S. 2003. Ilmu Tanah. Akademi Presindo. Jakarta

Heddy, S., W.H. Nugroho, dan M. Kurniati. 1994. Pengantar produksi Tanaman dan Penanganan Pasca Panen. PT Raja Grafindo Persada. Jakarta

Husen, E. and R. Saraswati. 2003. Effect of IAA-producing bacteria on the growth of hot pepper. J. Mikrobiol. Indonesia 8(1): 22-26.

Imaseki, H. 1986. Ethylene. In N. Takahashi (Ed.). Chemistry of Plant Hormones. CRC 
Press Inc. Boca Raton, Florida. p. 249264.

Kloepper, J.W., M.S.Reddy., D.S. Kenney., C. Vavrina., N. Kokalis-Burelle., and N. Martinez-Ochoa. 2004. Applications for rhizobacteria in transplant production and yield enhancement. Acta Hort. 631: 219229

Kokalis-Burelle, N., J.J.J.W. Kloepper, and M.S. Reddy, 2006. Plant growthpromoting rhizobacteria as transplant amendments and their effects on indigenous rhizosphere microorganism, Appl. Soil Ecol. 31: 91-100

Kucey, R.M.N. 1983. Phosphate-solubilizing bacteria and fungi in various cultivated and virgin Alberta soils. Can. J. Soil Sci. 63: 671-678.

Mayak, S., T. Tirosh, and B.R. Glick. 1997. The influence of plant growth promoting rhizobacterium Pseudomonas putida GR12-2. p. 313-315. In A. Ogoshi et al. (Eds.). Plant Growth-Promoting Rhizobacteria, Present status and Future Prospects. Proceedings of the Fourth International Workshop on PGPR. JapanOECD Joint Workshop. Sapporo, Japan. October 5-10, 1997.

Mullins, M.G. 1972. Auxin and ethylene in adventitious root formation in Phaseolus aureus(Roxd.).In: Carr DJ (ed) Plant growth substances 1970. Springer-Verlag, New York, pp 526-533
Okon, Y., and C. A. Labandera-Gonzalez. 1994. Agronomic applications of Azospirillum. An evaluation of 20 years worldwide field inoculation. Soil Biol. Biochem. 26:1591-1601

Rein, W. H., R. D. Wright, and D. D. Wolf. 1991. Stock plant nutrition influences the adventitious rooting of 'Rotundifolia' holly stem cuttings. J. Environ. Hort. 9:83-5.

Rukmana, R. 1997. Usahatani Melati. Yogyakarta: Kanisius

Sarwar, M., M. Arshad, D.A Martens, dan W.T. Frankenberger Jr. 1992. Tryptophandependent $*$ nsure** esis of auxins in soil. Plant and Soil 147: 207-215

Shukla, R.R. 2013. Jasminum Officinale LinnAyurvedic Aproach. International Journal of Ayurvedic And Herbal Medicine 3(1): 1114-1119

Struve, D. K. 1981. The relationship between carbohydrates, nitrogen and rooting of stem cuttings. Plant Propagator 27:6-7

Tien, T.M., M.H. Gaskins, and D.H. Hubell. 1979. Plant growth substances produced by Azospirillum brasilense and their effect on the growth of pearl millet (Pennisetum americanum L.). Appl. Environ. Microbiol. 37: 1.016-1.024.

Wibowo, R. 1999. Refleksi Pertanian: Tanaman Pangan dan Hortikultura Nusantara. Jakarta, Pustaka Sinar Harapan 